\title{
Endocrine regulation and extended follow up of longitudinal growth in intrauterine growth-retarded rats
}

\author{
E C A M Houdijk, M J T Engelbregt, C Popp-Snijders \\ and $\mathbf{H}$ A Delemarre-vd Waal \\ Departments of Pediatrics and Clinical Endocrinology, Research Institute for Endocrinology, Reproduction and Metabolism, University Hospital \\ 'Vrije Universiteit', de Boelelaan 1117, 1007 MB Amsterdam, The Netherlands \\ (Requests for offprints should be addressed to E C A M Houdijk, Department of Pediatric Endocrinology, University Hospital 'Vrije Universiteit', \\ PO Box 7057, 1007 MB Amsterdam, The Netherlands; Email: h.delemarre@azvu.nl)
}

\begin{abstract}
Bilateral uterine artery ligation in late gestation was performed in pregnant dams in order to determine the effects of intrauterine growth retardation (IUGR) on long-term postnatal somatic growth and the GH neuroendocrine axis in the adult female and male rat. Body weight $(\mathrm{BW})$, nose-anus length (NAL) and tail length (TL) were recorded at regular intervals in both the IUGR and control (CON) offspring until the age of 93 days. Spontaneous 6-h GH secretory profiles and serum IGF-I were determined around the age of 100 days in both the IUGR and the CON group.

No catch-up growth in BW, NAL or TL was observed in young adult male IUGR rats. Female IUGR rats did catch up in NAL beyond the age of 57 days and in TL before weaning, but did not catch up at any time in BW. Spontaneous 6-h GH secretory profiles in female and male
\end{abstract}

IUGR rats at a mean age of $100 \pm 4$ days were similar to their controls at a mean age of $101 \pm 4$ days. Overall median 6-h rat GH plasma concentrations, rat GH peak amplitude, number of rat $\mathrm{GH}$ peaks and sum of peak area were not significantly different. Median serum IGF-I levels in young adult female and male IUGR rats showed no difference when compared with their respective controls.

These results demonstrate that IUGR, after bilateral uterine artery ligation in late gestation, leads to incomplete BW catch-up growth in young adult rats of both sexes with physiological GH/IGF-I secretion, suggesting intrauterine modulation of tissue responsiveness to $\mathrm{GH}$ and IGF-I. Female IUGR rats do catch up in NAL and TL, developing disturbed body proportions.

Journal of Endocrinology (2000) 166, 599-608

\section{Introduction}

Intrauterine growth retardation (IUGR) in children is generally known to be a common cause of persistent short stature, as approximately $8-12 \%$ of the children born smallfor-gestational age do not achieve complete catch-up growth in adulthood (Karlberg \& Albertsson-Wikland 1995, Leger et al. 1997, Albertsson-Wikland et al. 1998). The exact mechanism of incomplete catch-up growth in IUGR children is not fully understood. The primary hormonal regulators of postnatal growth are growth hormone $(\mathrm{GH})$ and insulin-like growth factor-I (IGF-I), whereby the growth capacity of peripheral tissues appears to depend on the response to GH, hepatic IGF-I and locally synthesized IGF-I (D’Ercole et al. 1984, Cohick \& Clemmons 1993). Subnormal GH secretion and reduced IGF-I levels are described in a subset of short IUGR children (ThieriotPrevost et al. 1988, De Waal et al. 1994, AlbertssonWikland et al. 1998); however, GH resistance may also play a role in the inability to grow properly after IUGR (Gluckman \& Harding 1997, Chatelain et al. 1998).
Several animal models have been designed in order to reveal a catch-up growth momentum and the possible hormonal regulation of this mechanism by GH and IGF-I. Analysis of the pulsatile GH pattern in rats has shown either increased GH secretion linked to the catch-up growth mechanism after fasting (Mosier et al. 1985) and after cortisone injections (Mosier \& Jansons 1985) or reduced plasma GH concentrations after temporary early life dietary restriction (Harel \& Tannenbaum 1995). The decreased IGF-I levels due to nutritional restriction in growth-retarded rats normalize during nutritional rehabilitation and subsequent catch-up growth (Thissen et al. 1994). A comparable rapid normalization of IGF-I levels is seen during catch up after thyroxine replacement therapy in hypothyroidism (Mosier et al. 1977) and during recovery after cortisone treatment (Mosier et al. 1976).

The timing and the duration of the growth-retarding insult seem to be crucial for the occurrence of catch-up growth in the rat. Limited nutritional intake during different phases of pregnancy and during lactation in the rat results in different degrees of growth retardation in 
the offspring (Williams et al. 1974a,b, Garofano et al. 1998). However, in general, accelerated growth with complete catch up can be shown after a sufficient period of long-term follow up in growth-retarded rats (Williams et al. 1974b, Woodall et al. 1996b).

Unilateral and bilateral uterine artery ligation of the pregnant rat in late gestation is an animal model which appears to mimic third trimester IUGR in the human (Bussey et al. 1985, Ogata et al. 1986, 1990). The in utero-deficient nutrient flow gives rise to varying degrees of growth retardation in the rat fetus (Vileisis \& D'Ercole 1986, Unterman et al. 1993) and no catch up in body weight gain is observed (Ogata et al. 1985, Jansson \& Lambert 1999). However, information concerning longterm postnatal growth and possible changes in the $\mathrm{GH} /$ IGF-I axis related to the inability to catch up in this animal model is still lacking.

The aim of this study was to determine the long-term effects of IUGR induced by bilateral uterine artery ligation in the last trimester of gestation on postnatal growth and to evaluate the somatotrophic axis in the male and female IUGR rat in young adulthood.

\section{Materials and Methods}

\section{Animals and experimental procedure}

Timed pregnant Wistar rats (Harlan CPB, Austerlitz, The Netherlands) weighing between 250 and $300 \mathrm{~g}$ were housed individually in $42 \times 25 \mathrm{~cm}$ cages containing fine wood chips as bedding and with free access to tap water and normal rat chow (AM-II; $24.8 \%$ protein, $6.6 \%$ fat, $1 \%$ vitamin, $4.5 \%$ minerals and $3.6 \%$ crude fibre; Hope Farms $\mathrm{BV}$, The Netherlands) and allowed to acclimate for $24 \mathrm{~h}$ before surgery. The room was maintained at constant humidity and temperature $\left(23 \pm 1{ }^{\circ} \mathrm{C}\right)$ with a $12-\mathrm{h}$ light:12-h darkness cycle (lights on between 0600 and $1800 \mathrm{~h})$.

On day 17 of pregnancy a laparotomy was performed. General anaesthesia was induced by an intramuscular injection of ketamine (Aescoket ${ }^{\circledR}$; Aesculaap BV, Boxtel, The Netherlands)/xylazine (Rompun ${ }^{\circledR}$; Apharmo, Duiven, The Netherlands) (3:1 solution, $0 \cdot 1 \mathrm{ml} / 100 \mathrm{~g}$ body weight $(\mathrm{BW}))$ after ultrashort ether anaesthesia. A modified Wigglesworth method (Wigglesworth 1964, Ogata et al. 1985) was performed under aseptic conditions, the uterus exposed and the total number of fetuses in each horn counted. Both uterine arteries were ligated by a 5-0 Vicryl (Johnson and Johnson, Amersfoort, The Netherlands) suture. The uterus was returned to the abdominal cavity and the incision closed. Sham-operated pregnant rats underwent an identical procedure without ligation and their pups served as controls. All mothers recovered quickly after surgery. The pregnancy was allowed to continue to term with ad libitum feeding and water. Following spontaneous vaginal delivery around day
22, newborn pups in the IUGR group were considered growth retarded when initial BW (iBW), measured within $24 \mathrm{~h}$ of birth, was below -2 s.D. of the mean $\mathrm{iBW}$ of the sham-operated control (CON) pups. Mean iBW of the female and male CON pups was $6 \cdot 4 \pm 0 \cdot 6 \mathrm{~g}$.

Because of the limited number of live-born pups in the IUGR group the litter size was kept at three to four pups per lactating mother, regardless of sex. In the sham-operated CON group, litters consisted of six pups per lactating mother. The lactating mothers were given a normal diet and water ad libitum. Pups were weaned at day 25 and were housed in either triplets (females) or pairs (males) and allowed free access to normal rat chow and tap water.

Longitudinal growth in all animals was followed up from day 2 to day 93 of age. BW, nose-anus length (NAL) and tail length (TL) were recorded at days 2, 4, 10, 15, 22, 29, $35,51,57,64,71,78,86$ and 93 in 16 female and 14 male rats in the IUGR and in 17 female and 16 male rats in the CON group. BW was measured on a digital scale (Mettler P1200) with an accuracy of $0 \cdot 1 \mathrm{~g}$. NAL, from tip of nose to anus and TL, from anus to tip of tail were measured along a standard ruler $(\mathrm{cm})$. Longitudinal growth with regard to $\mathrm{BW}$ in both sexes was followed up only in a small subset of two female IUGR and six CON rats, as well as two male IUGR and four CON rats until 18 months.

Cannulation was performed in both the IUGR and CON animals between days 93 and 102. Under general anaesthesia with ketamine (Aescoket $\left.{ }^{\circledR}\right) / x$ ylazine (Rompun ${ }^{\circledR}$ ) in a solution of 3:1 $(0 \cdot 1-0 \cdot 15 \mathrm{ml} / 100 \mathrm{~g} \mathrm{BW})$ injected intramuscularly, after ultrashort ether anaesthesia, an incision in the neck was made and a catheter (polyethylene PP 50 with a Silastic tip) was implanted in the right jugular external vein. The cannula was then tunnelled under the skin behind the right ear, exteriorized between the shoulder blades and led through a spring (length approximately $30 \mathrm{~cm}$ ) which was fixed, subcutaneously, on the back of the animal. Patency of the cannula was secured by injecting a solution of polyvinylpyrrolidon (PVP), $0.9 \% \mathrm{NaCl}$ and heparin $(0.5 \mathrm{~g}$ PVP and $50 \mathrm{U}$ heparin $/ \mathrm{ml} 0.9 \% \mathrm{NaCl}$ ) in the catheter and repeated once the following day. After surgery the animals were placed, separately, in isolation test chambers and the spring, containing the cannula, was attached to a swivel so that the animal could move around freely. They were given free access to regular rat chow and tap water and left to recover for 4-6 days.

At a mean age of $100 \pm 4$ days in the IUGR and $101 \pm 4$ days in the CON group, the 6-h GH sampling in eight female and six male IUGR as well as in six female and six male CON rats was performed. On the morning of the experiment, after a cannula patency check, one basal blood sample of $350 \mu \mathrm{l}$ was withdrawn and subsequently blood samples $(50 \mu \mathrm{l})$ were withdrawn every $10 \mathrm{~min}$ for a period of $6 \mathrm{~h}(0800-1400 \mathrm{~h})$. Blood samples were centrifuged and the plasma separated and stored at $-20{ }^{\circ} \mathrm{C}$ for measurements of the different hormones. The protocol was 
Table 1 Characteristics of progeny of rats from dams that underwent bilateral uterine artery ligation in late gestation and from control sham-operated dams. Values are expressed as means \pm S.E.M. The number of animals in each group is in parentheses

\begin{tabular}{|c|c|c|c|c|}
\hline & $\begin{array}{l}\text { CON } \\
\text { females }\end{array}$ & $\begin{array}{l}\text { IUGR } \\
\text { females }\end{array}$ & $\begin{array}{l}\mathrm{CON} \\
\text { males }\end{array}$ & $\begin{array}{l}\text { IUGR } \\
\text { males }\end{array}$ \\
\hline \multicolumn{5}{|l|}{ Body weight } \\
\hline At birth (g) & $\begin{array}{l}6 \cdot 5 \pm 0 \cdot 001 \\
(17)\end{array}$ & $\begin{array}{l}4 \cdot 7 \pm 0 \cdot 1^{* *} \\
(16)\end{array}$ & $\begin{array}{l}6 \cdot 6 \pm 0 \cdot 001 \\
(16)\end{array}$ & $\begin{array}{l}4 \cdot 9 \pm 0 \cdot 001^{* *} \\
(14)\end{array}$ \\
\hline At weaning (g) & $\begin{array}{l}88 \cdot 0 \pm 1 \cdot 5 \\
(17)\end{array}$ & $\begin{array}{l}73 \cdot 8 \pm 2 \cdot 7^{* *} \\
(16)\end{array}$ & $\begin{array}{l}92 \cdot 2 \pm 1 \cdot 9 \\
(16)\end{array}$ & $\begin{array}{l}74 \cdot 2 \pm 2 \cdot 4^{* *} \\
(14)\end{array}$ \\
\hline At sampling (g) & $\begin{array}{l}253 \cdot 2 \pm 3 \cdot 5 \\
(6)\end{array}$ & $\begin{array}{l}211 \cdot 6 \pm 6 \cdot 9^{* *} \\
(8)\end{array}$ & $\begin{array}{l}433 \cdot 5 \pm 10 \cdot 4 \\
(6)\end{array}$ & $\begin{array}{l}363 \cdot 2 \pm 7 \cdot 4^{* *} \\
(6)\end{array}$ \\
\hline At 510 days (g) & $\begin{array}{l}350 \cdot 7 \pm 9 \cdot 6 \\
(6)\end{array}$ & $\begin{array}{l}299 \cdot 5 \pm 16 \cdot 5^{*} \\
(2)\end{array}$ & $\begin{array}{l}589 \cdot 0 \pm 13 \cdot 8 \\
(4)\end{array}$ & $\begin{array}{l}515 \cdot 0 \pm 20 \cdot 0^{*} \\
(2)\end{array}$ \\
\hline
\end{tabular}

CON, progeny of sham-operated dams; IUGR, progeny of dams after bilateral uterine artery ligation in late gestation.

${ }^{*} P<0 \cdot 01,{ }^{* *} P<0 \cdot 001$ compared with control group.

approved by the Animal Ethical Committee of the University 'Vrije Universiteit' at Amsterdam.

\section{Hormone assays}

Rat $\mathrm{GH}$ (rGH) was measured in heparinized plasma samples by radioimmunoassay using reagents supplied by NIDDK-NIH (Torrance, CA, USA). To assay the samples, $100 \mu \mathrm{l}^{125}$ I-labelled rGH (5000-7000 c.p.m.) and rGH antibody (1:945 000 final concentration) were added to $10 \mu \mathrm{l}$ heparinized plasma and incubated overnight at room temperature. $\mathrm{rGH}$ standards $(0-800 \mathrm{ng} / \mathrm{ml})$ were prepared by doubling dilutions in human serum. To separate the antibody-bound fraction, a mixture of $100 \mu \mathrm{l}$ of a second antibody and $500 \mu \mathrm{l} 6 \%$ polyethyleneglycol was added to the tubes. After incubation at room temperature for $30 \mathrm{~min}$, the tubes were centrifuged, the supernatant was decanted and the pellet was counted for radioactivity. Results are expressed in $\mathrm{ng} / \mathrm{ml}$ in terms of the NIDDK standard RP-2, and represent the mean of duplicate determinations. The intra-assay coefficient of variation was $10 \cdot 6-13 \cdot 6 \%$ and the lowest detectable concentration of plasma $\mathrm{rGH}$ was $6 \mathrm{ng} / \mathrm{ml}$.

Serum IGF-I was measured in the basal blood sample by a human radioimmunoassay suitable for the measurement of rat IGF-I (Medgenix Diagnostics, Belgium). Results are expressed in $\mathrm{ng} / \mathrm{ml}$.

\section{Statistical analysis}

rGH data from repetitive blood samples were analyzed using PC PULSAR program version $2 \cdot 1$ (Merriam \& Wachter 1982). Peaks were assigned a value of 0.05 for baseline calculations. The mean rGH level after smoothing was subtracted from PC PULSAR-identified rGH peaks to obtain amplitudes. The cut off value for peak splitting was set at $2 \cdot 7$. The ' $G$ ' criteria for determining significant pulses were: $G(1), 3 \cdot 80 ; G(2), 2 \cdot 60 ; G(3), 1 \cdot 90 ; G(4)$, 1.50; $G(5), 1 \cdot 20$. Data were analyzed in eight female
IUGR and six male IUGR rats as well as in six female $\mathrm{CON}$ and six male CON rats. Group differences in individual pulse parameters were analyzed using the Mann-Whitney U test (non-parametric test/SPSS).

Differences in growth parameters between groups were evaluated with a Student's $t$-test at separate time points and with MANOVA (BMDP5V, general autoregression and 1st order autoregression) to determine changes in time. Statistical significance was assigned to $P$ values of $<0 \cdot 05$.

\section{Results}

\section{Overall survival rate}

A total of 34 pregnant rats underwent laparotomy. Another seven pregnant rats were sham-operated. Overall survival rate of the pups was $41 \%$ (pups counted in utero: 359; pups live born: 148) in the IUGR group and 97\% (pups counted in utero: 89; pups live born: 86) in the shamoperated group. Of the live-born pups in the IUGR group only $25 \%$ were growth retarded with iBW $<5 \cdot 2 \mathrm{~g}$ within $24 \mathrm{~h}$ after birth. A small proportion of IUGR pups $(<5 \%)$ died in the first week with $\mathrm{iBW}<3.0 \mathrm{~g}$.

\section{Longitudinal somatic growth}

iBW (BW within $24 \mathrm{~h}$ of birth) in the IUGR offspring was $26 \%$ decreased in the male and $28 \%$ in the female pups compared with their respective controls $(P<0 \cdot 001)$. Percentage $\mathrm{BW}$ change from day 1 to weaning was not different in the IUGR offspring (93.6\%) versus the CON (92.6\%) juvenile animals. At the time of the 6-h GH sampling BWs in the severely growth-retarded IUGR offspring (iBW $<-2$ s.D. mean $\mathrm{BW}$ of controls) were significantly lower $(P<0 \cdot 01)$ than $\mathrm{BW}$ in control rats of the same sex (Table 1). 


\section{females}
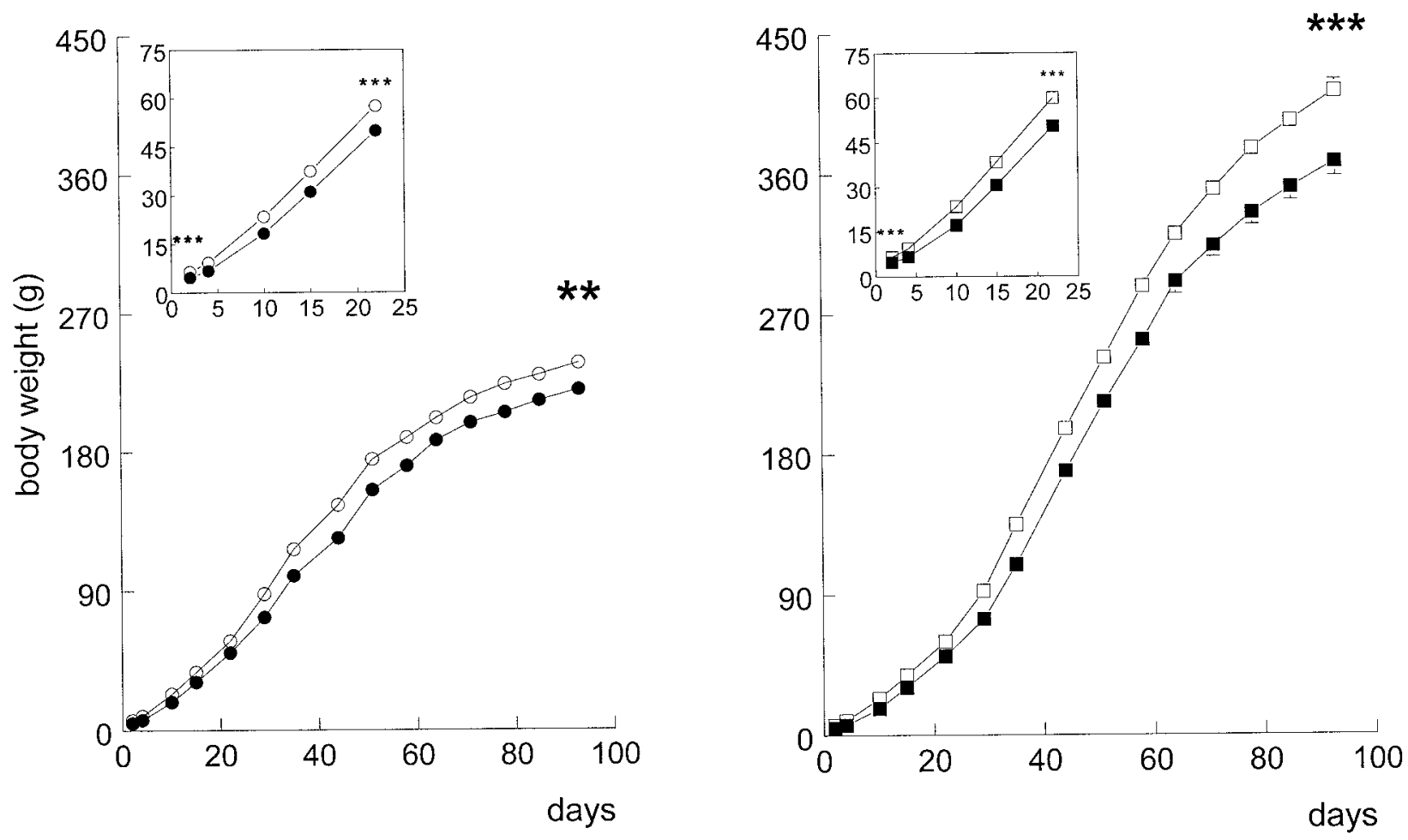

Figure 1 BW from 2 to 93 days of age in (left-hand graph) female $(\bullet, n=16)$ and (right-hand graph) male ( $\mathbf{\square}, n=14)$ IUGR rats after bilateral uterine artery ligation in late gestation and in sham-operated female $(O, n=17)$ and male $(\square, n=16)$ control (CON) rats. The insets show BW from day 2 to day 22. Data are presented as means \pm S.E.M. ${ }^{* *} P<0 \cdot 01,{ }^{* *} P<0 \cdot 001$ compared with CON rats.

Females Figure 1 (left-hand graph) shows the significantly lower BW from day 2 to day 93 in the IUGR female rats. NAL in the female IUGR rats was significantly reduced $(P<0 \cdot 05)$ from day 2 to 57 compared with female controls, but catch up in NAL did occur thereafter (Fig. 2, left-hand graph). TL in this group was significantly reduced prior to day $22(P<0 \cdot 01)$. From day 22 until adulthood, TL in the female IUGR rats was not significantly different from the CON group (Fig. 3a).

Males Figure 1 (right-hand graph) shows the significantly lower BW from day 2 to day 93 in the IUGR male rats. NAL remained significantly reduced $(P<0.05)$ in male IUGR rats from day 2 to day 93 (Fig. 2, right-hand graph). The same applied to TL, which was significantly reduced compared with that of the CON group throughout the study period (Fig. 3b).

\section{The GH secretory pattern}

Representative 6-h rGH profiles from female and male IUGR and CON rats are shown in Fig. 4. Table 2 summarizes the 6-h rGH profiles in both sexes in the IUGR and CON group.

Females All females in the IUGR group showed similar rGH secretion when compared with their CON counterparts. The median 6-h rGH was 21.9 (range: $9 \cdot 5-30 \cdot 1$ ) vs 15.4 (range: $11 \cdot 4-28 \cdot 4) \mathrm{ng} / \mathrm{ml}$ and median baseline $\mathrm{rGH}$ was $14 \cdot 0$ (range: $8 \cdot 7-22 \cdot 4$ ) vs $11 \cdot 4$ (range: 6.9-15.4) $\mathrm{ng} / \mathrm{ml}$. The median number of $\mathrm{rGH}$ peaks was $1 \cdot 0$ (range: $0 \cdot 0-3 \cdot 0)$ vs $2 \cdot 0$ (range: $0 \cdot 0-3 \cdot 0$ ), the median sum of peak area was $1590 \cdot 6$ (range: $0 \cdot 0-4103 \cdot 2$ ) vs $756 \cdot 0$ (range: 0.0-1981.0) $\mathrm{ng} / \mathrm{ml} . \mathrm{min}$ and the median $\mathrm{rGH}$ peak amplitude was $36 \cdot 4$ (range: $0 \cdot 0-105 \cdot 5$ ) vs 32.9 (range: $0 \cdot 0-56 \cdot 5) \mathrm{ng} / \mathrm{ml}($ Table 2$)$.

Males When comparing male IUGR rats with male $\mathrm{CON}$ rats no significant difference in the $\mathrm{rGH}$ secretory pattern was found. Male IUGR rats showed a median 6-h rGH of $24 \cdot 5$ (range:18.5-32.0) vs $23 \cdot 2$ (range:14.5-28.9) $\mathrm{ng} / \mathrm{ml}$ and a median baseline $\mathrm{rGH}$ of $9 \cdot 7$ (range: $8 \cdot 1-$ $12 \cdot 7$ ) vs $9 \cdot 0$ (range: $6 \cdot 1-11 \cdot 8$ ) $\mathrm{ng} / \mathrm{ml}$. The median number of $\mathrm{rGH}$ peaks was $4 \cdot 0$ (range: $2 \cdot 0-5 \cdot 0$ ) vs $3 \cdot 0$ 


\section{females}

males
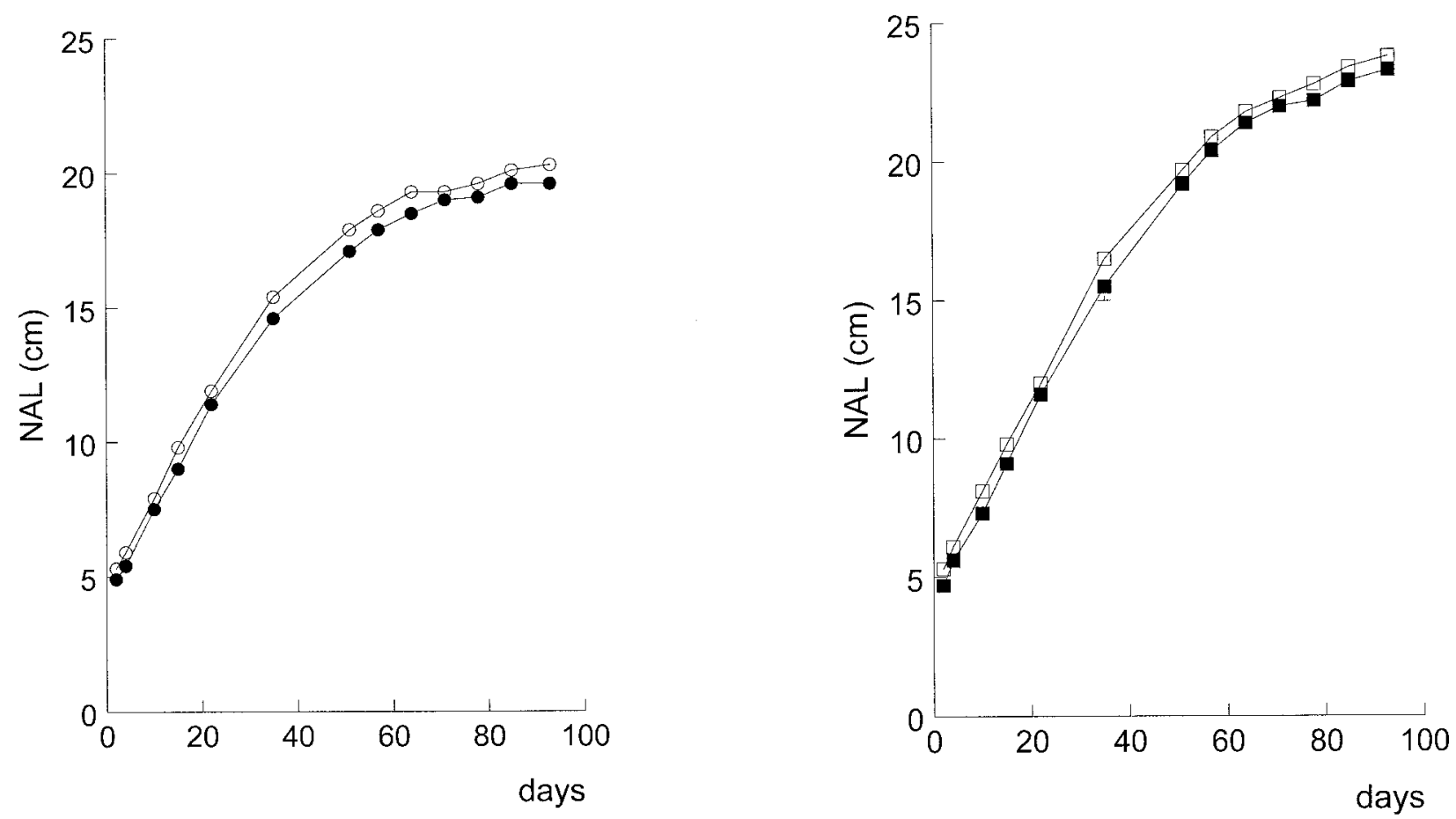

Figure 2 NAL from 2 to 93 days of age in (left-hand graph) female $(\bullet, n=16)$ and (right-hand graph) male $(\boldsymbol{\square}, n=14)$ IUGR rats after bilateral uterine artery ligation in late gestation and in sham-operated female $(\bigcirc, n=17)$ and male $(\square, n=16)$ control $(C O N)$ rats. Data are presented as means \pm S.E.M.

(range: $3 \cdot 0-7 \cdot 0$ ), the median sum of peak area was $1757 \cdot 8$ (range: $1549 \cdot 8-2068 \cdot 7$ ) vs $1295 \cdot 9$ (range: $795 \cdot 9-2963 \cdot 0$ ) $\mathrm{ng} / \mathrm{ml}$. min and the median rGH peak amplitude: $54 \cdot 0$ (range: $30 \cdot 1-98 \cdot 5$ ) vs $31 \cdot 8$ (range: $23 \cdot 0-67 \cdot 3$ ) $\mathrm{ng} / \mathrm{ml}$ (Table 2).

Within their group, IUGR male rats showed a significantly higher median number of rGH peaks compared with IUGR female rats $(P<0 \cdot 05)$. Median baseline rGH was significantly lower in males compared with females in the IUGR group $(P<0 \cdot 05)$.

\section{Serum IGF-I levels}

Females The serum IGF-I levels, obtained in adult female rats at the start of the 6-h rGH sampling, did not differ significantly between the female IUGR and CON rats with a median level of $780 \mathrm{ng} / \mathrm{ml}$ (range: 640-1000) vs $700 \mathrm{ng} / \mathrm{ml}$ (range: $260-1200)$ respectively (Table 2 ).

Males The serum IGF-I levels, obtained in adult male rats at the start of the 6-h rGH sampling, were not significantly different in the male IUGR versus CON rats with a median of $850 \mathrm{ng} / \mathrm{ml}$ (range: $560-1100)$ vs $940 \mathrm{ng} /$ $\mathrm{ml}$ (range: 860-1200) respectively (Table 2 ).

Within the IUGR group, serum IGF-I levels did not differ significantly when female rats were compared with male rats, nor did serum IGF-I concentrations differ between female and male rats in the CON group.

\section{Discussion}

The results of the present study demonstrate that IUGR caused by third trimester bilateral uterine artery ligation leads to persistent failure to catch up in BW in the young adult offspring. This is accompanied by a normal adult GH secretory pattern and circulating IGF-I at physiological levels at the mean age of 100 days in the female and male IUGR rat.

Bilateral uterine artery ligation in the last week of gestation in the pregnant rat, followed by natural birth of the IUGR rats, is an animal model mimicking placental insufficiency in the human (Ogata et al. 1985). Third trimester placental insufficiency in humans gives rise to 
a

females

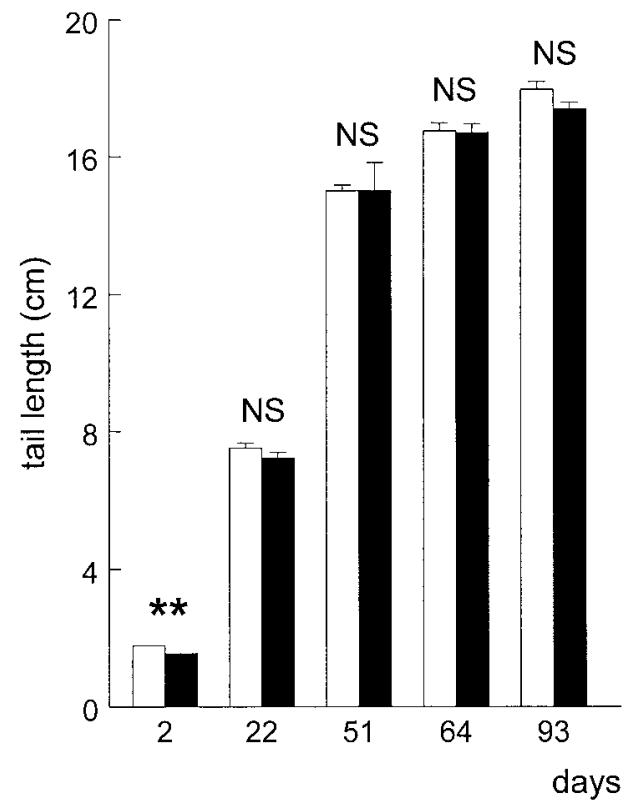

b

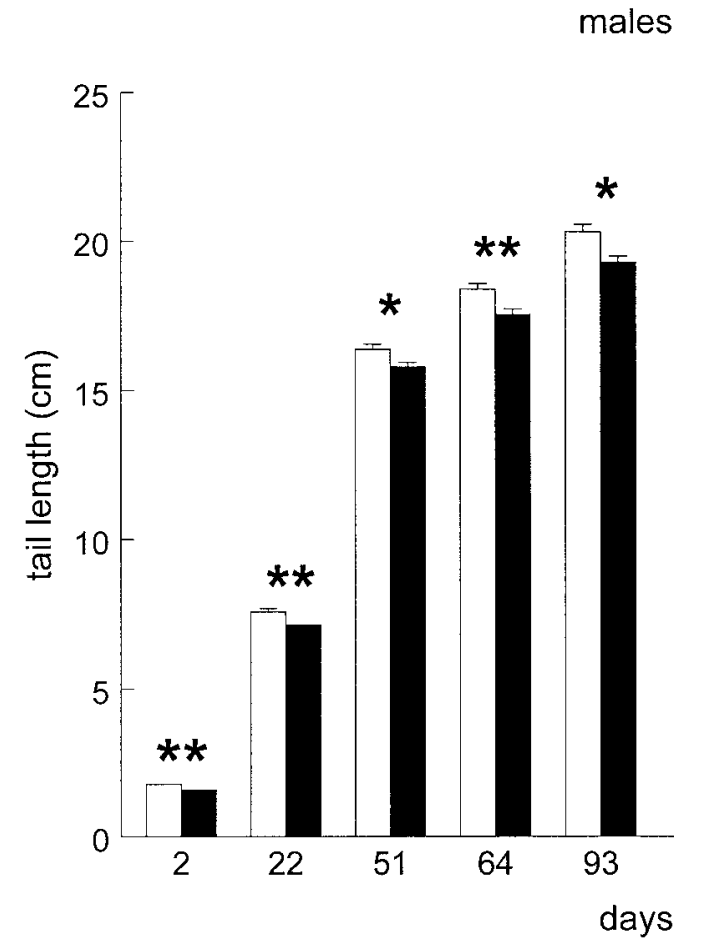

Figure 3 TL in 2-, 22-, 51-, 64- and 93-day-old (a) female and (b) male rats born from dams after bilateral uterine artery ligation in late gestation (IUGR: 16 females and 14 males; solid bars) or born from sham-operated mothers (CON: 17 females and 16 males; open bars). Values are given as means \pm S.E.M. ${ }^{*} P<0 \cdot 05$ ${ }^{* *} P<0 \cdot 01,{ }^{* * *} P<0 \cdot 001$ compared with CON rats.

\section{females}

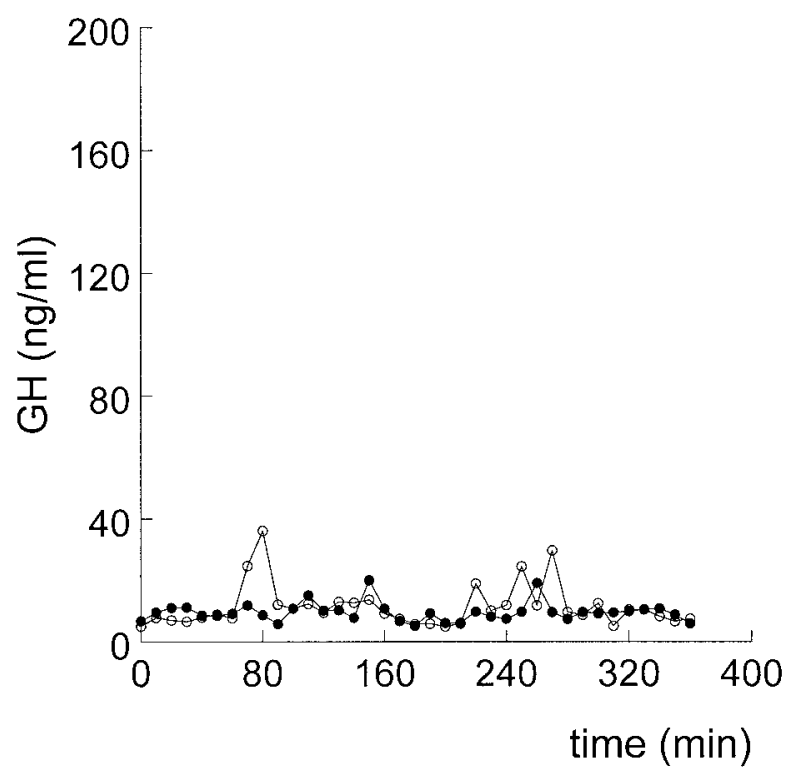

males

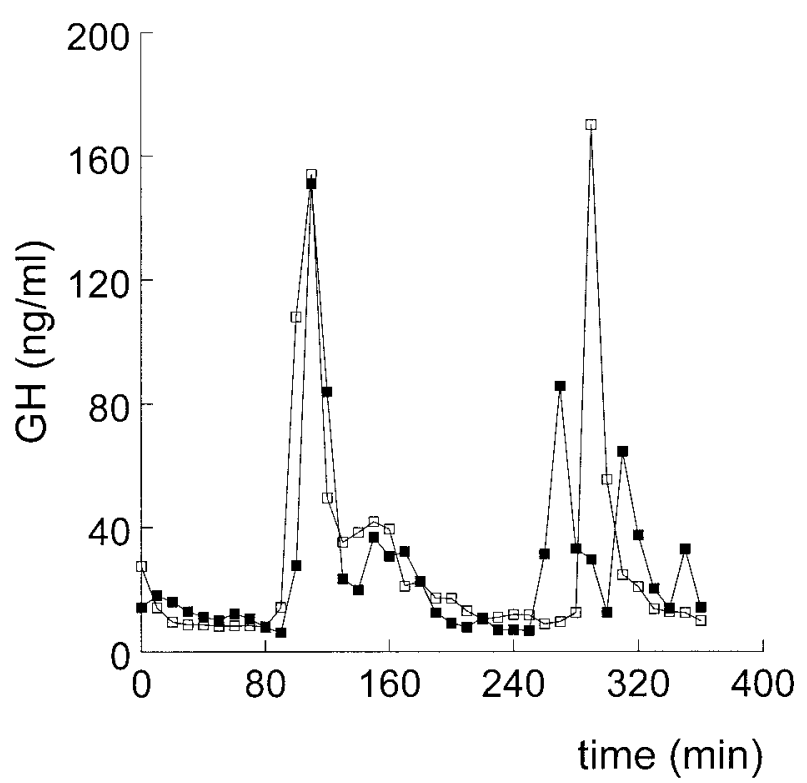

Figure 4 Representative 6-h GH secretory profiles in an IUGR ( and a sham-operated (control) female rat $(\bigcirc)$ (upper panel) as well as in an IUGR ( $)$ and a sham-operated (control) male rat $(\square)$ (lower panel). 
Table 2 Plasma 6-h rGH, baseline rGH, sum of peak area, number of rGH peaks and rGH peak amplitude as well as serum IGF-I in 100-day-old female and male rats with IUGR after bilateral uterine artery ligation and sham-operated controls (CON). Values are expressed as median (range) with the numbers in each group in parentheses

\begin{tabular}{|c|c|c|c|c|c|c|}
\hline & $\begin{array}{l}\text { GH } \\
(\mathrm{ng} / \mathrm{ml})\end{array}$ & $\begin{array}{l}\text { Baseline GH } \\
(\mathrm{ng} / \mathrm{ml})\end{array}$ & $\begin{array}{l}\text { Peak area GH } \\
(\mathrm{ng} / \mathrm{ml} \text {. per min) }\end{array}$ & $\begin{array}{l}\text { No. of } \\
\text { GH peaks }\end{array}$ & $\begin{array}{l}\text { GH peak } \\
\text { amplitude } \\
(\mathrm{ng} / \mathrm{ml})\end{array}$ & $\begin{array}{l}\text { IGF-I } \\
\text { (ng/ml) }\end{array}$ \\
\hline \multicolumn{7}{|l|}{ Group } \\
\hline CON female (6) & $\begin{array}{l}15 \cdot 4 \\
(11 \cdot 4-28 \cdot 4)\end{array}$ & $\begin{array}{l}11 \cdot 4 \\
(6 \cdot 9-15 \cdot 4)\end{array}$ & $\begin{array}{l}756 \cdot 0 \\
(0 \cdot 0-1981 \cdot 0)\end{array}$ & $\begin{array}{l}2 \cdot 0 \\
(0 \cdot 0-3 \cdot 0)\end{array}$ & $\begin{array}{l}32 \cdot 9 \\
(0 \cdot 0-56 \cdot 5)\end{array}$ & $\begin{array}{l}700 \\
(260-1200)\end{array}$ \\
\hline IUGR female (8) & $\begin{array}{l}21 \cdot 9 \\
(9 \cdot 5-30 \cdot 1)\end{array}$ & $\begin{array}{l}14 \cdot 0 \\
(8 \cdot 7-22 \cdot 4)\end{array}$ & $\begin{array}{l}1590 \cdot 6 \\
(0 \cdot 0-4103 \cdot 2)\end{array}$ & $\begin{array}{l}1 \cdot 0 \\
(0 \cdot 0-3 \cdot 0)\end{array}$ & $\begin{array}{l}36 \cdot 4 \\
(0 \cdot 0-105 \cdot 5)\end{array}$ & $\begin{array}{l}780 \\
(640-1000)\end{array}$ \\
\hline $\mathrm{CON}$ male $(6)$ & $\begin{array}{l}23 \cdot 2 \\
(14 \cdot 5-28 \cdot 9)\end{array}$ & $\begin{array}{l}9 \cdot 0 \\
(6 \cdot 1-11 \cdot 8)\end{array}$ & $\begin{array}{l}1295 \cdot 9 \\
(795 \cdot 9-2963 \cdot 0)\end{array}$ & $\begin{array}{l}3 \cdot 0^{*} \\
(3 \cdot 0-7 \cdot 0)\end{array}$ & $\begin{array}{l}31 \cdot 8 \\
(23 \cdot 0-67 \cdot 3)\end{array}$ & $\begin{array}{l}940 \\
(860-1200)\end{array}$ \\
\hline IUGR male (6) & $\begin{array}{l}24 \cdot 5 \\
(18 \cdot 5-32 \cdot 0)\end{array}$ & $\begin{array}{l}9 \cdot 7^{*} \\
(8 \cdot 1-12 \cdot 7)\end{array}$ & $\begin{array}{l}1757 \cdot 8 \\
(1549 \cdot 8-2068 \cdot 7)\end{array}$ & $\begin{array}{l}4 \cdot 0^{*} \\
(2 \cdot 0-5 \cdot 0)\end{array}$ & $\begin{array}{l}54 \cdot 0 \\
(30 \cdot 1-98 \cdot 5)\end{array}$ & $\begin{array}{l}850 \\
(560-1100)\end{array}$ \\
\hline
\end{tabular}

${ }^{*} P<0 \cdot 05$, males compared with females within each group (Mann-Whitney $U$ test (non-parametric test/SPSS)).

disproportionately growth-retarded newborns, who fail to catch up their longitudinal growth in 8-12\% of young adults (Leger et al. 1997, Albertsson-Wikland et al. 1998).

The degree of growth retardation can determine the ability to catch up. In humans, prematurity and severity of the growth retardation are poor prognostic factors for normal height attainment at 4 years (Fancourt et al. 1976) and at 2 years of age (Leger et al. 1997, Luo et al. 1998). The initially reported 15-40\% failure of catch-up growth in IUGR children (Fitzhardinge \& Inwood 1989, Albertsson-Wikland et al. 1993, Hokken-Koelega et al. 1995 ) is reduced to $8-12 \%$ if followed up into adulthood (Karlberg \& Albertsson-Wikland 1995, Leger et al. 1997, Albertsson-Wikland et al. 1998). A comparable situation is seen in animal studies. Mildly growth-retarded rats (birth weight between -1 and -2 s.D. below mean birth weight of the controls) after bilateral uterine artery ligation, with adequate postnatal nutritional intake, had already caught up in BW by the age of 14 days (Cha et al. 1987). Severely growth-retarded rats (birth weight below -2 s.D. of mean birth weight of the controls) in the same study did not catch up, but were only followed up for 14 days. Severe growth retardation, due to chronic maternal undernutrition, is followed by complete catch up in BW between 13 and 30 weeks of age in both female and male rats (Woodall et al. 1996b). These observations led to the hypothesis that the more severe the degree of growth retardation, the longer time it will take to catch up growth.

This study was therefore designed to follow up only the severely growth-retarded animals, defined as rats with a birth weight below -2 s.D. of mean birth weight of controls of either sex, for a prolonged period of time until they were 18 months of age. Interestingly, while the rate of BW gain in utero was clearly diminished, the rate of BW gain in the IUGR rats after postnatal day 10 was similar to the control animals, suggesting some initial catch-up growth. However, during the extended follow-up period we did not observe complete catch up in BW gain. There are several possible explanations for this failure to catch up.

A reduced ability of the IUGR pups to suckle could be responsible for the initial lack of catch up in BW. However, in our animal model, pups were nursed by one lactating mother with a maximum of four pups per mother, whereas 12-14 pups in this strain of rats is a normal litter size. Sufficient food intake is also demonstrated by equal growth rates in the IUGR and control pups during lactation in this study, as confirmed by others (Zeman 1970, Muaku et al. 1996), suggesting that IUGR pups receive an equivalent amount of milk, in proportion to their body size. In the young adult rats in our study, nutrient-induced insufficient catch-up growth is unlikely. Both serum IGF-I concentrations and GH secretion are not different from control rats and reflect adequate and comparable nutritional status (Thissen et al. 1994).

A reduced thyroid hormone level, known to impair the growth-promoting effect of GH (Glasscock et al. 1991), can cause growth failure in these IUGR rats. Serum levels of thyroid hormone at the age of 25 days are not different in our IUGR versus control rats (data not shown). Also in favour of normal and effective serum levels of thyroid hormone is the fact that female IUGR rats in our study show complete catch-up growth in TL, thought to be more dependent on thyroid hormone in the presence of both thyroid hormone and GH (Glasscock et al. 1991). However, catch-up growth in TL does not occur in the male IUGR rat and we do not have a good explanation for this difference between the sexes.

Failure to catch up growth in IUGR rats could be linked to changes in the GH/IGF-I axis. Reduced spontaneous $\mathrm{GH}$ secretion rate in combination with low serum IGF-I levels in IUGR children (De Waal et al. 1994, Albertsson-Wikland et al. 1998) are thought to contribute to persistent short stature in adulthood. Data on the GH secretory pattern in short young adults after IUGR have not been reported. 
In rats, as in the human, the central endocrine regulator of somatic growth is $\mathrm{GH}$, whose episodic secretion from the pituitary is regulated by both stimulatory (e.g. GHreleasing factor) and inhibitory (e.g. somatostatin) hypothalamic hormones. During pubertal development of the rat, $\mathrm{rGH}$ amplitude increases in both sexes and after the age of 54 days the typical pattern of low basal rGH secretion, combined with high-amplitude, low-frequency rGH pulses in the male versus the many small irregular peaks on a higher baseline $\mathrm{rGH}$ secretion in female rats is evident (Jansson et al. 1985, Gabriel et al. 1992).

Results from our study show that, in both female and male young adult IUGR rats, no differences were seen in the rGH secretory pattern when compared with controls at a mean age of 100 days. If the amount of spontaneously secreted rGH in the control rats is thought to be sufficient to induce normal growth, the measured concentrations of rGH in the IUGR rats in this study could be too low to permit catch-up growth to occur. Evidence for the necessity of increased peak rGH concentrations to induce catch-up growth comes from studies in adult rats after a short period of fasting (Mosier et al. 1985) or following glucocorticoid-induced growth inhibition (Mosier \& Jansons 1985). The absence of increased GH secretion in our experimental rats may be responsible for the lack of normalization of growth.

In the IUGR human and rat fetus, serum IGF-I is reduced with a concomitant increase in serum IGFbinding protein-1 (IGFBP-1), both correlating with fetal BW (Vileisis \& D'Ercole 1986, Unterman et al. 1993, Verhaeghe et al. 1993). In IUGR infants with failure to catch up growth, serum IGF-I levels are reported to be reduced in the first year of life (Thieriot-Prevost et al. 1988). Several other investigators have since confirmed the finding of decreased serum IGF-I levels (De Waal et al. 1994, Albertsson-Wikland et al. 1998) in relation to insufficient catch-up growth in prepubertal IUGR children. However, normal serum levels of IGF-I in prepubertal IUGR children are also reported (Rochiccioli et al. 1989, Leger et al. 1996). Data on serum IGF-I concentrations in short IUGR adults are lacking.

In the present study, serum IGF-I levels at the age of 14-15 weeks in both female and male persistently growthretarded rats were not different. The meaning of this is unclear. With the knowledge of decreased serum IGF-I levels in the IUGR rat around birth (Vileisis \& D'Ercole 1986, Unterman et al. 1993), the measured IGF-I concentrations in young adult rats in our study suggest a relative increase of circulating IGF-I to physiological levels. Despite this relative increase of IGF-I no complete catch-up growth was observed. The finding of physiological IGF-I levels without concomitant catch-up growth in adulthood, preceded by reduced IGF-I levels until day 9 postnatally, is also reported in another rat model in which IUGR is due to gestational nutritional restriction (Woodall et al. 1996a). Thus this relative increase of circulating
IGF-I fails to induce complete catch-up growth, independent of whether IUGR is caused by maternal nutritional restriction during pregnancy or an interruption of the utero-placental-fetal circulation in late gestation.

In this respect one can only speculate on possible mechanisms responsible for this failure to catch up growth. Serum IGFBP-1 and IGFBP-2 concentrations might be persistently increased with consequently diminished bioavailability of IGF-I (Drop et al. 1992). However, in young adult IUGR rats without catch-up growth after gestational nutritional restriction IGFBP-1 and -2 levels are not increased (Muaku et al. 1996, Woodall et al. 1996a). Furthermore, the IGF-I receptor, which modulates the physiological action of IGF-I (Leroith et al. 1995), could be substantially damaged or reduced in number due to undernutrition in utero. Another mechanism might also be a resetting of the IGF-I receptor to a lower level of response in several tissues, resulting in a relative IGF-I resistance. In general, information on the role of the IGF-I receptor in relation to catch-up growth is lacking. Future research should focus on the IGFBPs and the function of the IGF-I receptor at tissue level in these IUGR animal models.

In conclusion, our study shows that the long-term negative effect of severe IUGR after bilateral uterine artery ligation on postnatal growth in the rat is accompanied by a physiological GH/IGF-I axis. This experimental model can therefore be used to investigate pathophysiology of failure to catch up longitudinal growth in IUGR children with a normal GH/IGF-I axis.

\section{Acknowledgements}

The authors thank Ben van de Water and his staff at the Clinical Animal Laboratory of the University 'Vrije Universiteit' for animal care and assistance during surgical procedures. We also thank Lyset Rekers for her statistical support.

\section{References}

Albertsson-Wikland K, Wennergen G, Wennergen M, Vilbergsson G \& Rosberg S 1993 Longitudinal follow-up of growth in children born small for gestational age. Acta Paediatrica Scandinavica $\mathbf{8 2}$ 438-443.

Albertsson-Wikland K, Boguszewski M \& Karlberg J 1998 Children born small-for-gestational age: postnatal growth and hormonal status. Hormone Research 49 (Suppl 2) 7-13.

Bussey ME, Finley SL, LaBarbera A \& Ogata ES 1985 Hypoglycemia in the newborn growth retarded rat: delayed phosphoenol pyruvate carboxykinase induction despite increased glucagon availability. Pediatric Research 24 384-390.

Cha C-JM, Gelardi NL \& Oh W 1987 Growth and cellular composition in rats with intrauterine growth retardation: effects of postnatal nutrition. Journal of Nutrition 117 1463-1468.

Chatelain PG, Nicolino M, Claris O, Salle B \& Chaussain J 1998 Multiple hormone resistance in short children born with intrauterine growth retardation? Hormone Research 49 20-22. 
Cohick WS \& Clemmons DR 1993 The insulin-like growth factors. Annual Review of Physiology 55 131-153.

D'Ercole AJ, Stiles AD \& Underwood LE 1984 Tissue concentrations of somatomedin C: further evidence for multiple sites of synthesis and paracrine and autocrine mechanisms of action. PNAS $\mathbf{8 1}$ 935-939.

De Waal WJ, Hokken-Koelega ACS, Stijnen T, de Muinck KeizerSchrama SM \& Drop SL 1994 Endogenous and stimulated GH secretion, urinary GH excretion, and plasma IGF-I and IGF-II levels in prepubertal children with short stature after intrauterine growth retardation. The Dutch working group on growth hormone. Clinical Endocrinology 41 621-630.

Drop SLS, Schuller AGP, Lindenbergh-Kortleve DJ, Groffen C, Brinkman A \& Zwarthoff EC 1992 Structural aspects of the IGFBP family. Growth Regulation 2 69-79.

Fancourt R, Campbell S, Harvey D \& Norman AP 1976 Follow up study of small for date babies. British Medical Journal 1 (6023) 1435 1437.

Fitzhardinge PM \& Inwood S 1989 Long-term growth in small-for-date children. Acta Paediatrica Scandinavica 349 (Suppl) 27-33.

Gabriel SM, Roncancio JR \& Ruiz NS 1992 Growth hormone pulsatility and the endocrine milieu during sexual maturation in male and female rats. Neuroendocrinology 56 619-628.

Garofano A, Czernichow P \& Breant B 1998 Postnatal somatic growth and insulin contents in moderate or severe intrauterine growth retardation in the rat. Biology of the Neonate 73 89-98.

Glasscock GF, Gin KK, Kim JD, Hintz RL \& Rosenfeld RG 1991 Ontogeny of pituitary regulation of growth in the developing rat: comparison of effects of hypophysectomy and hormone replacement on somatic and organ growth, serum insulin-like growth factor-I (IGF-I) and IGF-II levels, and IGF-binding protein levels in the neonatal and juvenile rat. Endocrinology 128 1036-1047.

Gluckman PD \& Harding JE 1997 The physiology and pathophysiology of intrauterine growth retardation. Hormone Research (Suppl 1) 48 $11-16$.

Harel Z \& Tannenbaum GS 1995 Long-term alterations in growth hormone and insulin secretion after temporary dietary protein restriction in early life in the rat. Pediatric Research 38 747-753.

Hokken-Koelega ACS, de Ridder MA, Lemmen RJ, den Hartog H, de Muinck Keizer-Schrama SM \& Drop SL 1995 Children born small for gestational age: do they catch up? Pediatric Research $\mathbf{3 8}$ 267-271.

Jansson JO, Eden S \& Isaksson OGP 1985 Sexual dimorphism in the control of growth hormone secretion. Endocrine Reviews $\mathbf{6}$ $128-150$.

Jansson T \& Lambert GW 1999 Effect of intrauterine growth restriction on blood pressure, glucose tolerance and sympathetic nervous system activity in the rat at 3-4 months of age. Journal of Hypertension 17 1239-1248.

Karlberg J \& Albertsson-Wikland K 1995 Growth in full-term smallfor-gestational-age infants - from birth to final height. Pediatric Research 38 733-739.

Leger J, Noel M, Limal JM \& Czernichow P 1996 Growth factors and intrauterine growth retardation. II. Serum growth hormone, insulinlike growth factor (IGF) I, and IGF-binding protein 3 levels in children with intrauterine growth retardation compared with normal control subjects: prospective study from birth to two years of age. Study Group of IUGR. Pediatric Research 40 101-107.

Leger J, Limoni C \& Czernichow P 1997 Prediction of the outcome of growth at 2 years of age in neonates with intra-uterine growth retardation. Early Human Development 48 211-223.

Leroith D, Werner H, Beitner-Johnson D \& Roberts CT Jr 1995 Molecular and cellular aspects of the insulin-like growth factor I receptor. Endocrine Reviews 16 143-163.

Luo C, Albertsson-Wikland K \& Karlberg J 1998 Length and body mass index at birth and target height influences on patterns of postnatal growth in children born small for gestational age. Pediatrics 102 E721-E727.

Merriam GR \& Wachter KW 1982 Algorithms for the study of episodic hormone secretion. American Journal of Physiology 243 E310-E318.

Mosier HD Jr \& Jansons RA 1985 Increase in pulsatile secretion of growth hormone during failure of catch-up growth following glucocorticoid-induced growth inhibition. Proceedings of the Society for Experimental Biology and Medicine 178 457-461.

Mosier HD Jr, Jansons RA, Hill RR \& Dearden LC 1976 Cartilage sulfation and serum somatomedin in rats during and after cortisoneinduced growth arrest. Endocrinology 99 580-589.

Mosier HD Jr, Dearden LC, Jansons RA \& Hill RR 1977 Growth hormone, somatomedin and cartilage sulfation in failure of catch-up growth after propylthiouracil-induced hypothyroidism in the rat. Endocrinology 100 1644-1651.

Mosier HD Jr, Jansons RA \& Dearden LC 1985 Increased secretion of growth hormone in rats undergoing catch-up growth after fasting. Growth 49 346-353.

Muaku SM, Beauloye V, Thissen JP, Underwood LE, Fossion C, Gerard G, Ketelslegers JM \& Maiter D 1996 Long-term effects of gestational protein malnutrition on postnatal growth, insulin-like growth factor (IGF)-I, and IGF-binding proteins in rat progeny. Pediatric Research 39 649-655.

Ogata ES, Bussey ME, LaBarbera A \& Finley S 1985 Altered growth, hypoglycemia, hypoalaninemia, and ketonemia in the young rat: postnatal consequences of intrauterine growth retardation. Pediatric Research 19 32-37.

Ogata ES, Bussey ME \& Finley S 1986 Altered gas exchange, limited glucose and branched chain amino acids, and hypoinsulinism retard fetal growth in the rat. Metabolism 35 970-977.

Ogata ES, Swanson SL, Collins JW Jr \& Finley SL 1990 Intrauterine growth retardation: altered hepatic energy and redox states in the fetal rat. Pediatric Research 27 56-63.

Rochiccioli P, Tauber M, Moisan V \& Pinkowski C 1989 Investigation of growth hormone secretion in patients with intrauterine growth retardation. Acta Paediatrica Scandinavica 349 (Suppl) 42-46.

Thieriot-Prevost G, Boccara JF, Francoual C, Badoual J \& Job JC 1988 Serum insulin-like growth factor 1 and serum growthpromoting activity during the first postnatal year in infants with intrauterine growth retardation. Pediatric Research 24 380-383.

Thissen J-P, Ketelslegers J-M \& Underwood LE 1994 Nutritional regulation of the insulin-like growth factors. Endocrine Reviews $\mathbf{1 5}$ 80-101.

Unterman TG, Simmons RA, Glick RP \& Ogata ES 1993 Circulating levels of insulin, insulin-like growth factor-I (IGF-I), IGF-II, and IGF-binding proteins in the small for gestational age fetal rat. Endocrinology 132 327-336.

Verhaeghe J, van Bree R, van Herck E, Laureys J, Bouillon R \& van Assche A 1993 C-peptide, insulin-like growth factor I and II, and insulin-like growth factor binding protein-1 in umbilical cord serum: correlations with birth weight. American Journal of Obstetrics and Gynecology 169 89-97.

Vileisis RA \& D'Ercole AJ 1986 Tissue and serum concentrations of somatomedin-C/insulin-like growth factor I in fetal rats made growth retarded by uterine artery ligation. Pediatric Research $\mathbf{2 0}$ 126-130.

Wigglesworth J 1964 Experimental growth retardation in the foetal rat. Journal of Pathology and Bacteriology 88 1-13.

Williams JP, Tanner JM \& Hughes PC 1974a Catch-up growth in female rats after growth retardation during the suckling period: comparison with males. Pediatric Research 8 157-162.

Williams JP, Tanner JM \& Hughes PC $1974 b$ Catch-up growth in male rats after growth retardation during the suckling period. Pediatric Research 8 149-156.

Woodall SM, Breier BH, Johnston BM \& Gluckman PD 1996a A model of intrauterine growth retardation caused by chronic 
maternal undernutrition in the rat: effects on the somatotrophic axis and postnatal growth. Journal of Endocrinology 150 231-242.

Woodall SM, Johnston BM, Breier BH \& Gluckman PD 1996 b

Chronic maternal undernutrition in the rat leads to delayed postnatal growth and elevated blood pressure of offspring. Pediatric Research 40 438-443.
Zeman FJ 1970 Effect of protein deficiency during gestation on postnatal cellular development in the young rat. Journal of Nutrition $100530-538$.

Received 26 June 1999

Accepted 26 April 2000 